\title{
RULE BY GOOD PEOPLE: Health Governance and the Violence of Moral Authority in Thailand
}

\author{
DAENA AKI FUNAHASHI \\ Aarhus University \\ (D) http://orcid.org/0000-0002-3015-5391
}

Yok made no effort to hide her look of disapproval. She had arranged to pick me up in front of my apartment in eastern Bangkok, but had caught me outside the shrine of the neighborhood's tree spirit, deep in conversation with Praew, a street vendor who sold chilled drinks to the spirit's devotees. As Praew described her dream to me, one in which she saw this week's winning lottery numbers in the folds of the spirit's tangled hair, Yok urged me into her sedan. The minute I closed the door, she could hold back no longer: "What idiots [man ngom ngai]! . . . What do they know?"

In the privacy of the car, Yok chided me for encouraging what she called "primitive country beliefs." As we drove past the corrugated metal walls of Praew's alley, adorned with faded political campaign stickers, Yok became even more visibly irritated. The stickers featured the face of Thaksin Shinawatra, ousted by a military coup in 2006, and his sister Yingluck, prime minister at the time of my research in 2012 but soon to be deposed in another coup in 2014. "This is the problem," said Yok, pointing her finger and catching in its sweep the political stickers, the tree spirit's shrine, and Praew all at once.

Yok worked as a health expert for Thai Campaign for Health (TCH), a statefunded organization that had gained an expanded role in public policymaking under the military junta of 2006. ${ }^{1}$ Yok and other conservative health experts at $\mathrm{TCH}$ claimed that, in the face of increasing political polarization and the loss of 
confidence in national juridical and legal mechanisms to implement necessary reforms, independent and apolitical bodies such as health organizations ought to intervene in the name of the common good. As Yok continued her tirade, she drew a clear link between the "idiocy" she saw in believing in the dreams sent by tree spirits and the "idiocy" of believing in the dreams of capitalist self-advancement spread by the Shinawatras. According to Yok:

Many Thai people . . . still believe in spirits and don't have wisdom [panya]. [They believe that] you can be that person you see in the movie . . . [and that] all you have to do [to become that person] is to buy the same iPhone, the same car, the same whatever it is. If you don't have mental immunity

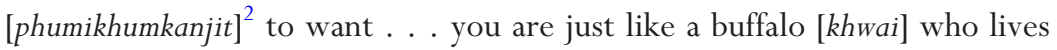
only to gratify its senses. . . . At $\mathrm{TCH}$, we try to educate the masses, but they don't listen!

Yok and other conservative health experts in the larger realm of public health blamed Thaksin and Yingluck's reinvention of the nation as "Thailand, Inc." for having caused negative environmental, social, and health-related consequences. For these health experts, the repeated electoral victories of the Shinawatras despite these self-evident (at least to some) flaws proved that the voting majority lacked what they termed "mental immunity" to the cunning of politicians, and that, like "buffalo," they were incapable of voting for the greater good. Together with the anti-Shinawatra street movements of 2013 and 2014, ${ }^{3}$ many health experts saw the military intervention as a necessary evil and demanded that the task of governance fall to "good people" (khon di). By good people, they meant those with a mental immunity to economic interests or party politics, those who could guarantee good governance from the basis of scientific, technical, and medical knowledge (or what the junta claimed as "moral truths"). More specifically, people like themselves.

The junta-written constitution of 2007 gave such claims legal legitimacy. The junta, having just wrested power from Thaksin, appealed to the apolitical basis of their intervention by enshrining in the new constitution the World Health Organization's (WHO) Health in All Policies (HiAP) initiative. The initiative redefined negative health outcomes as a natural limit to political ambition and capitalist expansion. According to the WHO, HiAP was intended to promote good governance and social equity by making population health "an overarching goal shared by everyone" (Kickbusch and Gleicher 2012, vi). Audit tools, such as the Health Impact Assessment (HIA), were to open new opportunities for con- 
cerned citizens to advocate for the making of "healthy public policy" (Kickbusch and Gleicher 2012, ix) — public policy driven by concerns for the common good, rather than by party politics or economic interests. Especially significant in light of the junta's attempts to depoliticize the political nature of their rule was the WHO's advocacy of a "knowledge society [where] power and authority are no longer concentrated in government" (Kickbusch and Gleicher 2012, vi).

In Thailand, the HiAP initiative as a legal mandate gave health experts jurisdiction over all aspects of public policymaking that affected national well-being. The mandate was intentionally broad, allowing for interventions in a wide variety of contexts, including anti-tobacco and alcohol campaigns, opposition to industrial development along Thailand's coast, and pressure to keep youth from violent or inappropriate television programming. Yet while the WHO sees HiAP as a globally applicable initiative that can be deployed in locally meaningful ways (Kickbusch and Buckett 2010), the way in which the Thai junta adapted HiAP into a monarchical and Buddhist framework of righteous rule, ${ }^{4}$ as I demonstrate below, reveals an inherent problem in assuming that the particular local capture of a global initiative successfully preserves the supposedly global aspirations in the original. Health reframed within dharmic notions of wisdom (panya) and enlightenment holds within it political implications unrepresentable in nondharmic political worlds.

However, seeing the Thai adaptation of HiAP as an idiosyncratic diversion from an otherwise universal convergence would be to replicate Yok's dismissal of Praew's world (that is, to say that Yok simply does not understand health). As Akhil Gupta $(1998,216)$ argues in his now-seminal piece on the status of indigenous knowledge, there ought to be other ways of talking about how local knowledge is imagined against the presumed universality of Western science, rather than as a mere mistranslation or cultural alternative.

Isabelle Stengers's (2005) cosmopolitical proposal opens another frame through which to approach this problem. Rather than probing into the emergence of new knowledge that forms at the interface of the modern/rational/universal and the traditional/cultural/particular as a hybrid that destabilizes these dichotomies, Stengers invites us to turn our attention instead to what remains incommensurable. Inasmuch as we all occupy particular ontological horizons, the problem lies not so much in pitting one perspective against another, but in opening ourselves to the possibility of a radically other idea of politics, economics, and ethics. This includes having to consider, as Marisol de la Cadena (2010) does, entities such as "earth beings" as having a legitimate claim to modern politics, as 
well as to take seriously the idea that cotton cries and beans kill (Hetherington 2013). In this sense, Stengers allows us to question the assumption that we can speak for a common world.

Finding inspiration in this approach, I take the Thai adaptation of HiAP as a challenge to the notion that modern science can, from a universally valid standpoint, answer "the political question par excellence: Who can talk of what, be the spokesperson of what, represent what?" (Stengers 2005, 995). For the WHO, which sees health as a global common good, health represented an apolitical basis on which to evaluate local governments. While the WHO makes HiAP as it is mobilized by $\mathrm{TCH}$ experts equivalent to its own initiative, the ways in which HiAP is reframed within monarchical and Buddhist terms by the TCH manifest the radical incommensurability of these two notions of health. The disjuncture between these two different worlds, one in which health is biomedically determined and the other in which health is dharmically determined, thus opens an interstice through which we can question the basis of what we mean by "global" health and the promotion of "good governance."

Based on ethnographic fieldwork conducted between the years 2011 to 2014 at the TCH headquarters in downtown Bangkok, as well as at associated organizations, I examine the unintended consequences of assuming that positive knowledge can guarantee good governance. Specifically, I examine how the notion of the good as something that exists separately from public referendum mobilizes a conservative politics that justifies the rendering of citizens into "buffalo," as well as the use of military violence.

With health as the standard measure of one's ability to choose wisely (or healthily), experts such as Yok, along with conservative political forces, leave no room for individuals like Praew to speak except as those in need of care. Here, contra Stengers, who finds potential for radical democracy through engagement with divergent ontological horizons, the TCH's take on health as a way to define its legitimacy as "good people" in the eyes of those its members call "idiots" does not support such optimism. Taking conservative health experts like Yok seriously, then, means to see them as not just putting into motion health-based governance that challenges the biomedical hegemony inherent within WHO discourse, but also as individuals equally equipped with hegemonic powers of their own. An analysis of the Thai translation of HiAP within a Buddhist genealogy of ethics thus reveals how the antipolitics (Redfield 2012) of a global health movement unintentionally sustains the fantasies of an authoritarian regime. 
At the same time, the TCH's claim to be an apolitical advocate of the common good places it in a double bind. In the eyes of an increasingly skeptical public, the activities of conservative health experts who benefited from the military intervention against a democratically elected government appeared political and in the service of the ancien régime. In the face of such opposition, I see the use of slurs by Yok and her colleagues to refer to individuals like Praew as "idiots" with the mental capacity of a "buffalo" (a mere beast of burden to whom political agency should not be granted) as a symptom of their inability to justify their claim to goodness without appearing too self-interested or lacking the very mental immunity to politics that they espoused. In this way, the double bind points to the problem of defining what counts as legitimacy when what counts as legitimate must emerge from a strictly antipolitical register.

\section{BIOMEDICAL UNIVERSALISM AND ITS ANTIPOLITICS}

In looking at how HiAP as a global movement enabled Thai conservative health experts to position themselves as good people unmoved by national party politics, I build on anthropological examinations of how interventions made in the name of humanitarian and/or biomedical necessity nonetheless deploy their own political and moral reasoning (Fassin 2011; Pandolfi 2003; Ticktin 2011). Whether in the form of bearing witness to psychic scars as recordable evidence of oppression (Fassin 2008), diagnosing symptoms in ways that entitle individuals to new forms of biological citizenship (Petryna 2002), or determining who will receive life-sustaining treatment in the face of limited medical supplies (Nguyen 2010), medical anthropologists have shown how health experts claim to act in the name of a good conceived as universally applicable, but which in fact stems from a specific (i.e., liberal, Western) lineage of morality (cf. Redfield 2005). The explicitly antipolitical drive behind these medical interventions offers, in Peter Redfield's (2012, 452) terms, a glimpse into politics “'beyond' politics,” an increasingly relevant form of antipolitics in the face of emergent biosecurity concerns that require global responses.

We can examine HiAP as one point of entry through which international organizations such as the WHO connect local health experts, nongovernmental organizations, and community activists in what Andrew Lakoff $(2010,60)$ calls “'apolitical' linkages” that allow experts to reach individuals in need across national boundaries. The creation of such links based on bioscientific authority has opened new pathways for health experts to work with different sectors of society and to take on responsibilities formerly belonging to national governments, responsi- 
bilities now recast within a global framework. Bioscientific knowledge and medical expertise thus make possible an imagined community of experts united as one against the political limitations and particularisms of nationally bound public health.

The WHO defines HiAP as a framework conducive to the creation of such apolitical links, and as an approach that allows experts and concerned citizens to have a say in policy decisions in a way that "systematically takes into account the health implications of decisions, seeks synergies, and avoids harmful health impacts, in order to improve population health and health equity" (WHO and the Ministry of Social Affairs and Health, Finland, 2013). Against national governments with eyes fixed on growing GDP and local politics operating to the detriment of the population's well-being, HiAP aimed to open up a space for monitory democracy by making health outcomes the key "factor[s] defining good governance" (Kickbusch and Gleicher 2012, 1). Moreover, the WHO has come to promote health as a "global public good" (Kickbusch and Gleicher 2012, 46), and, on the basis of this public good, health experts called on governments to review the health consequences of their goals and policies (e.g., fiscal, environmental, educational). Key to providing experts with the necessary concrete data was the Health Impact Assessment (HIA), an audit tool that linked negative health consequences to specific public policy. Using it, experts were expected to collaborate with other concerned actors to intervene in local decision-making processes. Significantly, by making good or bad governance determinable by the assessment of health outcomes, the HIA allowed such interventions to be made in the idioms of biomedical necessity.

But such a notion of health carries with it certain assumptions. For one, the treatment of health as part of a universal objective truth divorced from cultural, social, and political realities belies what Philippe Descola (2013, xv) calls a Western "naturalist" tradition, a tradition that categorizes human biology on the side of nature, the "domain of objects" against which human subjects exert their divergent influence. It is this treatment of health as a natural condition accessible via biomedicine, albeit through different institutional and national contexts, that gives purchase to the WHO's idea of health as a global public good.

It is, however, just when we rush into believing that our positive knowledge of the world can guarantee a definition of the common good that Stengers (2005, 994) insists we "slow down." Thailand's efforts to implement the HiAP and the HIA as a governance tool, while recognized by the WHO as part of the global movement for health governance (cf. Evans 2010), promotes fundamentally dif- 
ferent notions of health and the public good. Where the WHO, in the naturalist tradition, treats health as a shared biological condition that bears the mark of human influence, under Buddhist and monarchical readings, health outcomes matter not as mere effects, but as conditions indicative of the differential, innate capacities of individuals for political, moral, and social life. From this perspective, respective individual organs of the body politic speak through symptoms, such as the floods of 2011, environmental pollution, and farmer suicides, all of which gain social meaning as the failure of Yingluck Shinawatra's administration to make healthy public policy enabling the nation to thrive. The body, rather than a mute object and effect of individual agency, takes the position of a subject that reveals to the individual person his or her own lack of wisdom necessary to make healthy/ good choices.

Yet despite this incommensurable difference between the two frameworks of HiAP, the antipolitical emphasis at the core of this initiative resonated with attempts by anti-Thaksin forces in Thailand to intervene in the name of the people. Since the 1990s, King Bhumibol Adulyadej, or at least the large bureaucracy centered on promoting the Thai monarchy (see McCargo 2005), has attempted to curb an ethos of reckless consumerism (associated, at least since 2000, with Thaksin) by encouraging Thais to rein in aspirations for self-transformation via capital accumulation and to maintain goals appropriate to their station (Walker 2010). This push, officially known as the king's sufficiency economy theory (sethakit pho phiang), demands that one be mindful of what one has in everyday life, and explicitly targeted Thaksin's attempts to run the country as Thailand, Inc. (with Thaksin himself cast as the self-professed "CEO Prime Minister"). Those who espoused the king's theory framed Thaksin as a self-interested plutocrat who had bought the people's vote by sweet promises of wealth, and as an exploitative "lackey of foreign capital" (Surin 2007, 349). Many at the TCH who saw Thaksin's policies as having increased domestic indebtedness and health problems associated with the breakdown of traditional communal ties saw the monarchy as a necessary force against the moral overreach of profit-minded politicians. And, in the logic of the king's sufficiency theory, street protests and political demands made by Thaksin supporters thus became mobs incapable of simply being happy with their lot in life. When, in 2007, the military junta rewrote the constitution, these Buddhist-informed ideas of mindfulness and the ills of over-desirousness became firmly anchored to the notion of health governance as per HiAP.

The Thai Health Act of 2007, a key document that articulates the junta's elevation of health as the guarantor of good governance, clearly shows this fusion 
of the biological, moral, and political. The act places panya, wisdom, as a prerequisite for the attainment of health (sukhaphab; literally, "image of happiness"). The choice of the term panya is not accidental, as, unlike other terms for knowledge (e.g., khwam ru), panya is loaded with Buddhist significance. ${ }^{5}$ The act defines panya as "knowing in total," a totality here specified as a knowledge of "perfection," a state of always already knowing what will bring "evil" before seeing ill effects. Health, then, is the manifestation of one's "knowledge of falsehood and trickery, the ability to distinguish between good and evil, [to distinguish] what will have benefit and what will cause harm, [and one's ability to bring] this knowledge into consciousness in order to make oneself bountiful, beautiful, and good" (Thailand National Health Commission Office 2007, 1-2; my translation). In this way, the act pulls together wisdom, health, and morality as three aspects of human perfectibility.

The blurring of the division between these categories has a long history in Thailand. As Stanley Tambiah $(1977,98)$ argues in his now-classic work on the idea of healing, the Thai Buddhist cosmology makes "no separation between the workings of 'moral laws' and 'physical' or 'natural laws'; the concept of dhamma encompasses both." The power of those with panya is the capacity to act in tune with dharma, the "law of the universe, immanent, eternal, uncreated" (Gethin 2004, 519), a capacity, in other words, to make good decisions that precede all constructed notions of what constitutes goodness. In the Dhammacakkappavattana Sutta, for instance, the Buddha convinces critics doubtful of his enlightenment not through sermons, but through attaining a perfect state of well-being (Crosby 2014, 36). Those who can see his perfection move one step closer to understanding dharma, of how to be in line with and to think in terms of the quality of the entity that we are. Attaining health, the perfection of biological life, in this sense becomes the self-evident proof of one's all-knowing state.

Implicit in the explicit link between health and wisdom drawn by the act is a temporal element that sets the attainment of both on a karmic timeline. One's past moral behavior (one's kam [Sanskrit: karma]) determines access to panya and to resources in the present. As this moral account includes the balance of one's merits and demerits from another lifetime, health encompasses a condition that is not only the effect of one's immediate present but of events that took place beyond the knowledge of the individual. Thus, in the dharmic reading of health, human biology is not pitted against human action, but at that which lies at the core of why and how individuals have differential levels of panya, fortune, and the like. Poor health, then, reveals the limited capacity of those who imperfectly 
follow dharmic law, the law that would, for those who could comprehend its demands, allow one to prosper.

Andrew Alan Johnson $(2014,13)$ describes how, in Thai cosmological interpretations, these notions of karma and dharma order entities on earth, including gods and spirits, within a hierarchy of panya and enlightenment. Those occupying higher levels within this stratified order of entities have, owing to their lofty position, a panoramic vision of the world that begets them more panya. For instance, the dhammaraja, the divine king - a status often attributed to the Thai king Bhumibol (Jackson 2010) — is given a seat near the top from where he may see almost everything. Thus, while those with complete access to panya know "in total," those at lower levels have access to only limited visions of panya- that is, specialized knowledge — with those in even lower levels of the hierarchy (in with domesticated animals, recalling Yok's accusation of Praew as a "buffalo") have close to no panya.

In terms of governance, nothing good can thus come from rule under individuals lacking panya. Occupying lower levels of this cosmic hierarchy, they cannot see the consequences of their actions and can only cause more suffering. On the other hand, good governance comes from those with perfect health, those with mental immunity and total knowledge. Their knowledge of how to be within the cosmic order of things wards off sickness, strife, and social disorder. Health as a perfectible condition, albeit within the limits of one's karmic status, thus reveals the individual as a specific cosmological entity set on a path of reincarnation that is shaped by the moral choices made in past lives.

Experts like Yok at the TCH do not necessarily consider themselves on the top of the hierarchy of panya, but rather as those knowledgeable enough to mediate between beings and people on the higher rungs of dharmic wisdom and those situated below. For instance, Yok sees herself as a "coordinator," someone who relays information between community leaders, physicians, monks, public intellectuals, and royalty to bring diverse sectors of society together to make all more mindful of how health sits at the intersection of governance, policies, and individual life choices (see also Prawase 2000; Rasanathan et al. 2012, 3).

The implementation of HiAP in Thailand points to a fundamental problem inherent in the act of translation. In contrast to the WHO's intention of promoting monitory democracy around the world via HiAP, the translation and adaptation of HiAP in the Thai institutional context through the Thai Health Act of 2007 grants legitimacy to military rule. Health as it is translated within the frameworks of panya in the act reveals how divergent boundaries can be drawn in between 
matters of health, politics, and religion. As Talal Asad (2003) argues, such differences force us to rethink the secular-sacred divide built around Western assumptions, and to pay attention to what the irresolvable differences between worlds express. The $\mathrm{TCH}$ and the WHO meet in their reliance on the language of moral and biological necessity, reminiscent of age-old claims by health experts that "the struggle against disease must begin with a war against bad government" (Foucault 1994, 33). It is, as I expand here, a claim that mobilizes a certain fundamentalism foreclosing the possibility of politics. Where, as Claude Lefort (1986) argues, politics and those who speak in its register cannot self-authorize, those who speak for biology, health, and nature can. In the next section, I explore what shape good governance takes under the fundamentalism of HiAP in Thailand.

\section{GOOD GOVERNANCE}

The TCH is representative of many nongovernmental, semigovernmental, and royally funded organizations that formed around the turn of the millennium following a new wave in Thai politics that sought to improve mechanisms for participatory democracy through decentralization (Rasanathan et al. 2012). Key to this new movement was the People's Constitution of 1997, one of Thailand's most liberal, and, owing to the increased role of electoral democracy in it, a central reason for the rise to power of the populist Thaksin administration. Many senior workers at the TCH and in the larger NGO community embraced Thaksin's rise- but not for long. Shortly after his first election, Thaksin took an increasingly combative stance toward NGO networks, closed down media outlets, and butted heads with long-established royal patronage networks - exactly those networks that lay behind much of the NGO community. By the middle of the 2000s, many former supporters of the 1997 constitution and, indeed, of Thaksin himself, backed his ouster (Pasuk and Baker 2009, 228). Key among this group was Prawase Wasi, royal physician to the king, one of the 1997 constitution's architects, public intellectual, and advisor to the $\mathrm{TCH}$.

Prawase articulated an increasingly popular perspective in the NGO community that the liberal reforms introduced by the People's Constitution allowed politicians like Thaksin to abuse the system for his own political benefit (cf. Tejapira 2006). Pointing to how Thaksin promoted family members and those under his patronage into positions of power, Prawase argued that politicians "neither have the knowledge nor the competency [to rule]. . . . It is more suitable to call them election winners" (Walker 2006). Against politicians, he pitted in- 
dependent expert bodies as those capable of returning competence to Thailand's legal, political, and juridical system.

It is with this backdrop in mind that I return to Yok and her open frustration at Praew and the residents of her alley for proudly displaying election stickers from Thaksin's campaign. Yok, like many in the health community, idolized Prawase and argued that, after seeing firsthand the vulnerability of the electoral system to the tyranny of "election winners," respect for the common good can only come from those with mental immunity against moral overreach. For Yok and others like her, the problem of election winners like Thaksin amounted to the fact that, when cunning and the manipulation of the public allow individuals into positions of power, nothing but the will of the politician gains representation. The voice of the people becomes merely an echo of this will.

Yok's support of HiAP stems from her perspective that something other than the wile of politicians ought to ground authoritative power. She often stressed to me that elections proved nothing, and that good governance could only come from those with mental immunity to self-interest, those "good people." Faced with volumes of domestic and international press that critiqued the support of such a notion by individuals like Yok as "fascist," Yok characterized them all as "the point of view of those with no panya." Even as I showed up to her office armed with new clips from the media that described positions like Yok's as “authoritarian," Yok waved a hand, dismissing critical foreign press and Thai voices alike:

They don't understand. They see elections and think that, 'OK, [leaders that] come from [an] election are good.' They are 'demo-crazy' [in English]. But goodness for Thai people refers to something deeper than what foreigners [farang] can understand, and the evil, the corruption of Thaksin is deeper [than what they think they know].

"Demo-crazy" foreigners (here explicitly named by Yok as farang, ${ }^{7}$ a general term for Caucasians or Westerners) and the Thai academics who, in Yok's terms, "just follow the asses of the foreigners [tam kon farang]), ${ }^{8}$ fail to see that some votes are worth more than others. Good governance, that is, good in the dharmic sense, emerges neither from the democratic rule of numbers nor from legal, social, or political definitions of what is good, but through the capacity of those who can access a notion of the good existing independently from human machination. 
Good governance, thammaphibaan in Thai, has as its root word dharma (thamma) and points to rule emerging from those cosmic laws. Vibrant life, timely assurances of rain and fertility, and a peaceful public are all manifestations of a ruler consubstantial with dharma. In contrast, what characterizes bad governance is the use of amnat: "raw amoral power that may be used for either good or evil and which is accumulated and maintained by sheer force" (Jackson 2010, 33). The illegitimacy of amoral power is revealed through the emergence of sickness, famine, and misfortune, as the use of force necessary to put such a regime in power inevitably disrupts the cosmic balance indispensable to the attainment of dharmic perfection. The legitimacy of good governance is couched in terms of dharmic moral terms as an a priori good, and as that which needs no a posteriori justification. The power of those with panya, the capacity to act in tune with, or be one with dharma, simply is.

The historian Thongchai Winichakul (2008, 20-21) argues that the term democracy has been used in Thailand to refer not to a contested field in which the public debates and decides based on a rule of numbers, but to the framework through which those with panya intervene in the name of the people against selfinterested political forces abusing and manipulating the populace. Historically, the Thai monarch has served this role, cast as the dhammaraja who steps in as the moral authority above politics and as the symbolic figure who speaks for his or her people against the excesses of corrupt politicians or power-hungry generals. Present-day royalist groups like the People's Democratic Reform Committee (PDRC) thus draw on such an image of the king as divine ruler and father of the nation against inherently untrustworthy politicians. According to Thongchai, the strength of the monarchy in modern Thai politics stems from the notion that, without the king as the referee, corrupt politicians will twist the spirit of democracy to their own ends at the expense of the people.

The authority of health experts such as Yok and others at the TCH thus rides on a history of democracy that posits that, should those with panya ensure "clean politics," the national environment and its people will be healthy and prosperous. This act of cleansing, however, mobilizes the denigration of those cast as lacking panya. How can the vote of an individual with the panya of a buffalo be counted equal to that of someone with real knowledge? The notion that there are good people who are beyond or above politics makes the contest of legitimacy that characterizes political participation unnecessary. The good people have already obtained their legitimacy from universal, apolitical sources of goodness, wisdom, and nature; they need no vote. 
It is easy to dismiss Yok's argument as simply a political ploy supporting class conflict (Hewison 2012), a divide between rural and urban interests (Fong 2013), or as the effect of a struggle between competing elite groups (Connors 2012). But doing so would be to dismiss an entire cosmology of knowledge and power as authoritarian window dressing. For, as Benedict Anderson (1972) argues, narrowing down what counts as political theory to ideas of power in the West not only relegates all other traditional political concepts to be "cultural" variations on a general theory but also precludes inquiry into how these traditions live on to shape contemporary politics.

\section{GOOD PEOPLE}

The TCH office sat above a small street market where vendors like Praew sold snacks and drinks from their carts. Owing to TCH's role as a center for networking between other organizations, the offices were small, given the breadth of programs in which TCH participated. Different experts (like Yok) worked on community-level health-promotion programs, ranging from those specializing in the problem of drug and alcohol abuse to teams that assisted in analyzing social determinants of health at the policy level. Overlooking the street and the carts was the office's common room, with beige couches and a new espresso machine.

As I sat in the room with Yok and Tom, Yok's colleague, I looked down to the street. The sight of the vendors so soon after the outburst over Praew bothered me, and I brought Praew up again. "You don't understand," declared Yok. This time, however, she expanded on what she had said in her car that day in hushed tones. As we looked down onto the street together, she characterized those supporting Thaksin as suffering from anxiety. This suffering, she said, came from engaging in risky activities such as compulsive gambling, migrating to the city to seek better wages, holding unattainable desires premised on a rise in social status or class, and pursuing profit-oriented actions destructive to their health and to the environment in general. Popular religious practices associated with lottery playing also fell into this category of risky and speculative action driven by desirousness, and Praew represented exactly the type of individuals the TCH wanted to target in their push to promote mental immunity.

Tom, fiddling with the coffee in the espresso machine, piped up: "They have yet to open their eyes! They don't understand how dangerous greed can be. Caught up in this political fight, they can't stop thinking about demanding this and that from the country without once stopping to think, 'Why am I demanding?' 
They can never be happy if they can't understand what it means to have sufficiency [pho phiang]."

Tom worked with environmental activists on the impact of environmental degradation on health, and he often referred to the royal sufficiency economy theory to explain how ecological crises affecting national health were fundamentally a problem of moral overreach by greedy developers or overdesirous consumers. Moreover, he saw ecological damage, the loss of health, and the current political conflict as revealing how the cosmos itself - nature, biology, and social harmony - protested against the promotion of entrepreneurial greed by Thaksin, and that a return to good governance by good people was of a vital necessity.

In their respective programs, Tom and Yok both promoted panya as the basis for mental immunity against greed, as well as a means of knowing when needs have been sufficiently met. But while giving credit to the Thai monarch for having already warned his subjects of the repercussions of advanced capitalism (cf. Handley 2006) even before the promotion of the HiAP initiative by the WHO, Tom, Yok, and their colleagues at the TCH also took great pride in the fact that the WHO had recognized their activities as part of a global intervention in the name of the common good. Yok distinguished this sort of international attention from those pro-democracy groups that, according to Yok, evaluated Thai forms of governance against a privileged and universalized Western standard ("following the asses of the foreigners"). Instead, Yok and her colleagues viewed foreign WHO experts as "experts just like us," experts who understood the secret of their struggle. Tom summarized their position succinctly in a metaphor: "Children always resist when you need to give them an injection. But all good doctors know that a little unpleasantness is necessary in order to save lives."

"Good doctors know," said Tom, but such a need to declare the righteousness of his authority carried the inverse effect of calling attention to its limits. The need to keep referring to individuals like Praew as "idiots" or, here, as "children" emerges at the limits of the power to convince, to legitimate Tom's and Yok's righteous place within the hierarchy of panya without themselves appearing susceptible to the desire to impress and use force (amnat) in the political realm.

It is in light of such a world in which there exists correct knowledge, accessible only to those with the wisdom to see it, that I turn to the Dharma Gallery, where I saw an art exhibition to which Yok took me in May of 2012. I had been pestering her with questions about dharma, panya, and how they affect one's mental immunity. Instead of answering my questions, however, Yok offered 
to take me to see the gallery. Yok led me up the escalator to the elevated skywalk linking the malls at Ratchaprasong intersection, a walkway that led over the site where, on May 19, 2010, the military had shot at Red Shirts, pro-democracy protesters, who had gathered on the street below. ${ }^{9}$ The Dharma Gallery now occupied the place where snipers had hidden two years earlier. Even so, the night before our visit, Red Shirts had held a rally in memory of those killed and injured, and from the skywalk, we could see red pools of candle wax, each marking a place where someone had been shot. While neither Yok nor the gallery explicitly mentioned the clash, the timing of the exhibition and its location vis-à-vis the planned Red Shirt commemoration seemed deliberate, as did Yok's choice to take me there that day.

Yok followed my gaze down onto the street, but then encouraged me to read aloud the following from the plaque leading to the gallery:

Dharma is not just about going to the temple. It is about the everyday life of every individual. It is about happiness. It is about losing strong emotions such as want, greed, anger, and attachment. Dharma is with us in a traffic jam. It is with us in the fitting room. It is with us when we decide to buy. Dharma is with us everywhere, but we are not open enough to see it because we are not mindful in our everyday life.

Tapping at the last sentence, Yok said,

It is just like my king [in English] said, "The only change for the better is through mindfulness of dharma." Dharma is about feeling sufficient in yourself and not comparing what you have with your neighbor. We help individuals to be more attentive to how desire turns into suffering, and suffering into mental illness and social disorder. We try to protect the public from politicians with influence by teaching them that there are consequences to ignoring the law of dharma.

Yok made clear whom she meant by "the public" in need of protection by aiming her comments at the stained street below: "We don't want to be ruled by people who only want to do so for their own political or economic advantage. When Thaksin came into office, farmers and small business owners supported him because they thought that he would make them rich. But they actually got into more debt than before. Wanting him back just shows you how sick they are.” 
Yok defined sickness here as desire that "turns into suffering, and suffering into mental illness and social disorder." Thus political ambition and the frustration borne out of political disenfranchisement here manifest as symptoms of one's refusal to accept the natural order of things. As with the effort that goes into staving off the flow of the river to create dams, to cite one of Tom's favorite examples, going against nature comes with consequences. In this sense, rule under good people who follow the proper order of things ought to produce intended outcomes with minimal effort. That effort becomes necessary therefore reveals more about the qualities of the individual expert (that is, the expert is doing something wrong) than about the fact that rule by the good, or the notion of an absolute good, is itself a political perspective.

\section{CLEANSING POLITICS}

Yok's and Tom's characterization of legitimate individuals as those who can, with minimum effort, gain the confidence of others has its parallels in one of the most popular stories of the Buddha in Thailand. In this story, the Buddha is meditating in a grove when a divine being, Mara, approaches him. Mara attempts to lure the Buddha away from his meditations by promising him worldly power and a life of luxury and riches. The Buddha refuses, and when an angered Mara summons his minions to harm the Buddha, the Buddha lightly touches the ground with his fingertip. His holy touch wakens Mae Thorani, the earth goddess, who rises and wrings from her hair all of the lustral water that the Buddha had poured in religious devotion throughout all of his lives. The flood destroys Mara and his minions.

This destruction comes at minimum effort. No force other than the touch of the Buddha's finger brings forth the flood, since nothing more necessitates the release of water accumulated through his own rites of devotion. It is the earth goddess in the act of wringing out her hair that is enshrined on the seal of the Democrat Party, the political party most fervently advocating the military and opposing Thaksin.

Links between this story and the proper workings of dharma in the presentday conflict are commonplace. The Thai intellectual and Thaksin opponent Sulak Sivaraksa made the parallel between Thaksin and Mara explicit in the days leading to his ouster (Kitiarsa 2006, 4), and he invoked dharma as the means of his defeat (Sulak 2006). ${ }^{10}$ It was a narrative that many at TCH repeated when I asked about their varying positions on Thai politics. For opponents of Thaksin within the health community, the military coup of 2006 - a coup rumored to have occurred at the 


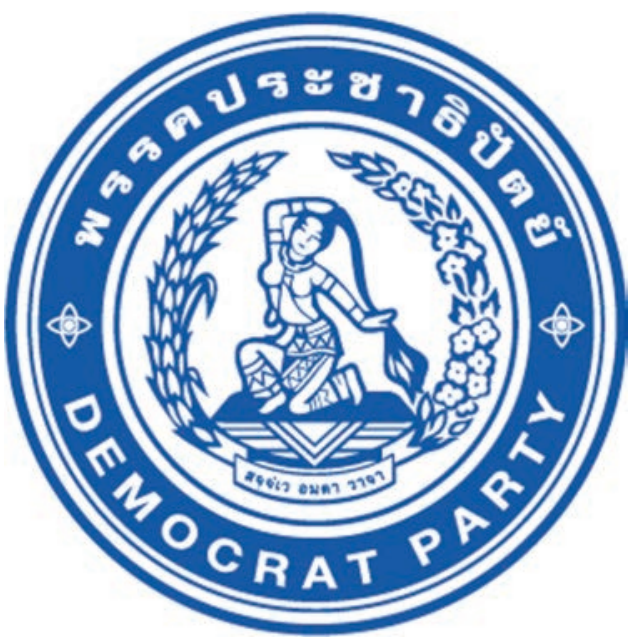

Figure 1. The seal of Thailand's Democrat Party.

behest of the palace — constituted a necessary evil. Thaksin was swept aside for having resisted dharma, and the political world was washed clean, ready for a new foundation.

But even supporters of the military such as Yok found it hard to justify the deaths and injuries caused to so many people, as the necessity of force made all too clear that merely claiming to speak from the perspective of dharma was not in itself convincing to an increasingly skeptical public. What was to be an a priori good not only failed to speak for itself but also relied on brute force for its implementation. I see the deferrals and roundabout ways in which experts explained the philosophy and mission of the TCH to me as themselves symptoms of contradictions that they cannot ignore.

The struggle by experts to present themselves as those with dharmic wisdom also manifested in other ways. Later, long after our visit to the Dharma Gallery, during a TCH-sponsored information session for youth on the importance of understanding the sufficiency economy as it relates to health and immunity to excessive consumerism, Yok was stunned when a participant asked her to explain again just how they were to know when need and want become moral overreach. Yok had just explained the importance of mindfulness to the group, and so the response to her address in the form of "how?" visibly upset her. In front of twenty politely waiting adolescents, I saw Yok's cropped hair swerve to and fro as she turned her head from the young inquirer to her two other colleagues. When the silence became awkward, one of Yok's colleagues stepped in and stated: "When 
you feel the desire to buy, or feel tempted to get the latest cell phone, for instance, you should repeat the name of the Buddha. Saying his name, 'Bud-dha [phut-tho],' 'Bud-dha [phut-tho],' 'Bud-dha [phut-tho],' like this multiple times, that should help you get over your temptation and help you think of more important things."

If adolescents who came to $\mathrm{TCH}$ through associated community projects disturbed Yok's calm, less accommodating audiences presented an even bigger challenge. Later, in private, when discussing the difficulty of convincing Thaksin's adult supporters of the health dangers inherent in their political views, Nui, another health expert, said in frustration: "Everything is political now, and it doesn't matter if you know the truth, they won't listen. You can't reason with them. If you want a buffalo to move, you have to strike it. That is the problem.”

In the next and final section, I expand on Nui's supposed problem to examine in detail how what health experts took to be good governance, a governance driven by the natural necessities of health (with the backing by the WHO), paradoxically mobilized a conservative politics, and what the deployment of HiAP in Thailand might reveal about the risks of relying on health experts to speak for the global common good.

\section{THE DOUBLE BIND OF ANTIPOLITICS}

Calling someone a buffalo marks that individual as a person with minimal capacity for self-mastery who lives only to gratify his or her senses. With no wisdom to distinguish right from wrong, such persons threaten harm to themselves, the environment, and the greater world in the process of satisfying their excesses. In a context where "everything is political" (itself a political or politicized statement), Nui believes that buffalo cannot be reasoned with; they follow only that which promises them the most benefits. One can only make them move in the "right" direction by striking them. This recourse to violence reveals not only what Nui sees as the limit of the buffalo's capacity for reason but also the limit of those who claim to have access to a truth beyond all social truths. Only those, as Hannah Arendt (1972) argues, with no power to produce consent must rely on brute force to impose what they consider right.

In play is a logic of exception that undermines health experts' ability to speak from the apolitical, authoritative standpoint of public health. As beneficiaries of the regime that forcibly ousted a popularly elected prime minister and violently suppressed a popular protest, experts' claim to speak for dharma and to act in the name of a transcendental moral law to return peace, harmony, and health to the nation has met with strong challenges. While health experts gained an ex- 
panded role in defining what counts as good governance since the interim military government of 2007 that ousted Thaksin, their legitimacy falters beyond the legally given capacity to tautologically claim their authority as just ("I am just because I possess the panya that allows me to know I am just"). Contrary to the global ambitions of the WHO to posit health outcomes as a politically neutral basis on which to evaluate public policy, the deployment of the HiAP in Thailand in ways that render certain segments of the population as buffalo has been anything but neutral.

According to Claude Lefort (1986), the notion of legitimacy in democratic regimes relies on the perception that such authorizing power belongs to everyone and thus to no one in particular. Power, then, comes from an "empty place" (Lefort 1986, 17) that no figure could fill without the risk of appearing to be an illegitimate usurper. The legitimate is in a constant state of contestation, as this lack of authoritative guarantee at the core of democratic regimes allows for multiple claims and counterarguments. The notion of rule by an unelected council of good people elides this struggle by covering over this empty place with a transcendental notion of the good, accessible only to those with panya.

Health experts have long played a significant role in moments of exception when threats to population health and conditions of existence call for coercive measures to place individuals in quarantine, to regulate nutritional intake, or to enforce discipline in the name of hygiene. But the use of health to bring elected governments into check, and in the Thai case, even to advocate for their removal altogether raises the political significance of experts to a new level. Yet as we see, Thai health experts fail to completely convince others that they speak on behalf of the common good and, when challenged, advocate increasingly violent and coercive means to convince a skeptical public of the legitimacy of their actions. Where the WHO sees the adoption of HiAP in Thailand as the growing relevance of this initiative worldwide, ${ }^{11}$ failing to see the incommensurable differences that appear in the Thai iteration of HiAP risks giving credence to the type of rule by good people promoted by conservative political forces in Thailand. Following Isabelle Stengers's argument, different ontological worlds demarcate the realm of politics (what entities count within it) and nature (as accessible via science or panya) in different ways, thus challenging our assumptions about what constitutes the world and how we ought to be within it for the better. Difference, according to Stengers, provides the possibility to imagine a radically new form of politics, an antidote to the hegemonic frameworks under which we currently live. What the case of HiAP in Thailand reveals, in contrast, is that the encounter with 
difference does not always open onto a new emancipatory horizon. Different ontological horizons in which wisdom, morality, and health make sense allow us to imagine other possibilities of being, but we must not forget that this encounter with otherness can also open onto new horrors.

\begin{abstract}
This article rethinks the presumed translatability of the World Health Organization's (WHO) health promotion models and explores the unintended consequences of their global export. Specifically, I focus on the Thai military government's adoption (2006-2008) of the Health in All Policies (HiAP) initiative, which redefined health outcomes as the standard universal measure against which the success of national public policy ought to be evaluated. Through my fieldwork at state-owned Thai health organizations, I track how a dharmic concept of wisdom (panya), one that links the capacity to make healthy choices with differential levels of enlightenment, undergirds the Thai adoption of HiAP, with political implications that are unrepresentable in nondharmic political worlds. I analyze the ramifications of framing a political intervention within the apolitical bioscientific register of medical necessity, and explore the effect that global health movements have on the status of political legitimacy and national political conflicts. [global health; cosmopolitics; knowledge practices; political legitimacy; experts; Thailand]
\end{abstract}

\title{
NOTES
}

Acknowledgments I thank the three anonymous reviewers and Cultural Anthropology's editorial collective: Dominic Boyer, James Faubion, and especially Cymene Howe, who helped guide this article to its completion. I am also deeply indebted to Hoon Song, Jeremy Fernando, Ulrika Backebo, and David Rojas for offering invaluable theoretical insights and critical commentary. Finally, I wish to thank Andrew Alan Johnson for sharing with me his wealth of knowledge on Thai popular religion, and for his support throughout.

1. TCH and the individuals to whom I refer on a personal basis are all protected here under pseudonyms.

2. Phumikhumkanjit has become a popular concept among many NGOs, mobilized in the context of anticonsumerism drives, efforts to stop farmers from being swindled by con artists selling "miracle seeds," and as a part of the promotion of the Thai king's sufficiency economy (Walker 2010).

3. These movements, in their latter form, took the name of the People's Democratic Reform Committee (PDRC), although the Thai name literally translates as the "People's Committee for Absolute Democracy with the King as Head of State" (Khaosod English 2013).

4. While Thailand is ostensibly multireligious, Theravada Buddhism is hegemonic. Roughly 95 percent of Thais identify as Buddhist, the Thai state casts itself as the guardian of religion (understood to be Buddhism), and the Thai monarch, the legal head of state, is required to be Buddhist. In Thai public discourse, Buddhism is seen to be synonymous with being ethnically and nationally Thai.

5. For instance, in everyday Buddhist practice, panya represents the highest of the three steps toward enlightenment, with the others being moral conduct and the practice of meditation (Crosby 2014, 55). 
6. Here, Tambiah uses the term dhamma, which is written as dharma (Sanskrit) in the Pali spelling and as thamma in Thai.

7. By framing this in racial terms, Yok may have been attempting to establish solidarity with me, another non-farang, who might be more sympathetic.

8. Accusations that those who disagree with mainstream or elite discourses are somehow inherently foreign abound in Thai nationalist discourse (Johnson 2013).

9. This clash between Red Shirt protesters who demanded elections and those advocating the repeal of lèse-majesté laws resulted in close to one hundred civilian deaths and more than one thousand injured (Sopranzetti 2012).

10. Sulak has, in the ten years since, become an advocate for democratic rule and an opponent of the current military government.

11. HiAP was first developed in Finland and promoted within the European Union under Finland's E.U. presidency.

\section{REFERENCES}

Anderson, Benedict

1972 “The Idea of Power in Javanese Culture.” In Culture and Politics in Indonesia, edited Arendt, Hannah by Claire Holt, 1-70. Ithaca, N.Y.: Cornell University Press.

1972 Crises of the Republic. San Diego, Calif.: Harcourt.

Asad, Talal

2003 Genealogies of Religion: Discipline and Reasons of Power in Christianity and Islam.

Connors, Michael

Baltimore, Md.: Johns Hopkins University Press.

2012 “Notes towards an Understanding of Thai Liberalism.” In Bangkok May 2010: Perspectives on a Divided Thailand, edited by Michael Montesano, Pavin Chachavalpongpun, and Aekapol Chongvilaivan, 97-107. Singapore: Institute of Southeast Asian Studies.

Crosby, Kate

2014 Theravada Buddhism: Continuity, Diversity and Identity. Oxford: Wiley-Blackwell. de la Cadena, Marisol

2010 "Indigenous Cosmopolitics in the Andes: Conceptual Reflections Beyond 'Politics." Cultural Anthropology 25, no. 2: 334-70. http://dx.doi.org/10. $1111 /$ j.1548-1360.2010.01061.x.

Descola, Philippe

2013 Beyond Nature and Culture. Chicago: University of Chicago Press.

Evans, Timothy

2010 “Foreword.” In "Implementing Health in All Policies: Adelaide 2010," edited by Ilona Kickbusch and Kevin Buckett, 2. Adelaide: Department of Health, Government of South Australia. http://www.who.int/sdhconference/ resources/implementinghiapadel-sahealth-100622.pdf.

Fassin, Didier

2008 "The Humanitarian Politics of Testimony: Subjectification through Trauma in the Israeli-Palestinian Conflict.” Cultural Anthropology 23, no. 3: 531-58. http:// dx.doi.org/10.1111/j.1548-1360.2008.00017.x.

2011 Humanitarian Reason: A Moral History of the Present. Berkeley: University of California Press.

Fong, Jack

2013 "Political Vulnerabilities of a Primate City: The May 2010 Red Shirts Uprising in Bangkok, Thailand." Journal of Asian and African Studies 48, no. 3: 332-47.

Foucault, Michel http://dx.doi.org/10.1177/0021909612453981.

1994 The Birth of the Clinic: An Archaeology of Medical Perception. Translated by A. M. Sheridan. New York: Vintage. 
Gethin, Rupert

2004 "He Who Sees Dhamma Sees Dhammas: Dhamma in Early Buddhism.” Journal of Indian Philosophy 32, no. 5: 513-42. http://dx.doi.org/10.1007/s10781004-8633-6.

Gupta, Akhil

1998 Postcolonial Developments: Agriculture in the Making of Modern India. Durham, N.C.: Duke University Press.

Handley, Paul

2006 The King Never Smiles: A Biography of Thailand's Bhumibol Adulyadej. New Haven, Conn.: Yale University Press.

Hetherington, Kregg

2013 "Beans Before the Law: Knowledge Practices, Responsibility, and the Paraguayan Soy Boom.” Cultural Anthropology 28, no. 1: 65-85. http://dx.doi.org/10. Hewison, Kevin $1111 /$ j.1548-1360.2012.01173.x.

2012 “Class, Inequality and Politics.” In Bangkok May 2010: Perspectives on a Divided Thailand, edited by Michael Montesano, Pavin Chachavalpongpun, and Aekapol Jackson, Peter Chongvilaivan, 141-60. Singapore: Institute of Southeast Asian Studies.

2010 "Virtual Divinity: A Twenty-First Century Discourse of Thai Royal Influence." In Saying the Unsayable: Monarchy and Democracy in Thailand, edited by Søren Ivarsson and Lotte Isager, 29-60. Copenhagen: Nordic Institute of Asian Studies Press.

Johnson, Andrew Alan

2013 "Moral Knowledge and its Enemies: Conspiracy and Kingship in Thailand." Anthropological Quarterly 86, no. 4: 1059-86. http://dx.doi.org/10.1353/anq. 2013.0052.

2014 Ghosts of the New City: Spirits, Urbanity, and the Ruins of Progress in Chiang Mai. Khaosod English Honolulu: University of Hawai'i Press.

2013 “Khaosod English's Note on Translation of Anti-Government Leadership Title 'PCAD.'” December 24. http://www.khaosodenglish.com/detail.php?newsid $=1387872575$.

Kickbusch, Ilona, and Kevin Buckett

2010 "Implementing Health in All Policies: Adelaide 2010." Adelaide: Department of Health, Government of South Australia. http://www.who.int/sdhconference/ resources/implementinghiapadel-sahealth-100622.pdf.

Kickbusch, Ilona, and David Gleicher

2012 "Governance for Health in the Twenty-First Century." Copenhagen: World Health Organization Regional Office for Europe. http://www.euro.who.int/ Kitiarsa, Pattana en/publications/abstracts/governance-for-health-in-the-21st-century.

2006 "In Defense of the Thai-Style Democracy." Paper delivered at the Asia Research Lakoff, Andrew Institute, National University of Singapore, October 12.

2010 “Two Regimes of Global Health.” Humanity: An International Journal of Human Rights, Humanitarianism, and Development 1, no. 1: 59-79. http://dx.doi.org/ 10.1353/hum.2010.0001.

Lefort, Claude

1986 The Political Forms of Modern Society: Bureaucracy, Democracy, Totalitarianism. Cambridge, Mass.: MIT Press.

McCargo, Duncan

2005 “Network Monarchy and Legitimacy Crises." Pacific Review 18, no. 4: 499-519. http://dx.doi.org/10.1080/09512740500338937. 
Nguyen, Vinh-Kim

2010 The Republic of Therapy: Triage and Sovereignty in West Africa's Time of AIDS. Durham, N.C.: Duke University Press.

Pandolfi, Mariella

2003 "Contract of Mutual (In)Difference: Governance and the Humanitarian Apparatus in Contemporary Albania and Kosovo." Indiana Journal of Global Legal Studies 10, no. 1: 369-81. http://www.repository.law.indiana.edu/ijgls/ vol10/iss1/13/.

Pasuk Phongpaichit, and Chris Baker

2009 Thaksin. Chiang Mai: Silkworm Books.

Petryna, Adriana

2002 Life Exposed: Biological Citizens after Chernobyl. Princeton, N.J.: Princeton University Press.

Prawase Wasi

2000 “'Triangle that Moves the Mountain' and Health Systems Reform Movement in Thailand." Human Resources for Development Journal 4, no. 2: 106-10. http:// www.who.int/hrh/hrdj/en/index6.html.

Rasanathan, Kumanan, Tipicha Posayanonda, Maureen Birmingham, and Viroj

Tangcharoensathien

2012 "Innovation and Participation for Healthy Public Policy: The First National Health Assembly in Thailand.” Health Expectations 15, no. 1: 87-96. http:// dx.doi.org/10.1111/j.1369-7625.2010.00656.x.

Redfield, Peter

2005 “Doctors, Borders, and Life in Crisis." Cultural Anthropology 20, no. 3: 328-61. http://dx.doi.org/10.1525/can.2005.20.3.328.

2012 "Humanitarianism." In A Companion to Moral Anthropology, edited by Didier Fassin, 451-67. Malden, Mass.: Wiley-Blackwell.

Sopranzetti, Claudio

2012 Red Journeys: Inside the Thai Red-Shirt Movement. Chiang Mai: Silkworm Books.

Stengers, Isabelle

2005 “The Cosmopolitical Proposal.” In Making Things Public: Atmospheres of Democracy, edited by Bruno Latour and Peter Weibel, 994-1003. Cambridge, Mass.: MIT Press.

Sulak Sivaraksa

2006 "Removing Thaksin Mindfully." ThaiDay, March 13. http://www.manager.co. th/IHT/ViewNews.aspx?NewsID=9490000033982.

Surin Maisreikrod

2007 "Learning from the 19 September Coup: Advancing Thai-Style Democracy?" Southeast Asian Affairs: 340-59. http://www.jstor.org/stable/27913340.

Tambiah, Stanley

1977 "The Cosmological and Performative Significance of a Thai Cult of Healing Through Meditation.” Culture, Medicine and Psychiatry 1, no. 1: 97-132. http://

Tejapira, Kasian dx.doi.org/10.1007/BF00114812.

2006 “Toppling Thaksin.” New Left Review 39: 5-37. http://newleftreview.org/II/ 39/kasian-tejapira-toppling-thaksin.

Thailand National Health Commission Office

2007 "Phraratchabanyat: Sukhaphap Haeng Chat [Thai National Health Act], B.E. 2550.” http: / / www.acfs.go.th/km/download/act_healthy_2550.pdf.

Thongchai Winichakul

2008 “Toppling Democracy.” Journal of Contemporary Asia 38, no. 1: 11-37. http:// dx.doi.org/10.1080/00472330701651937.

Ticktin, Miriam I.

2011 Casualities of Care: Immigration and the Politics of Humanitarianism in France. Berkeley: University of California Press. 
Walker, Andrew

2006 “Prawase Wasi’s Sufficiency Democracy.” New Mandala, November 29. http:// asiapacific.anu.edu.au/newmandala/2006/11/29/prawase-wasis-sufficiencydemocracy.

2010 "Royal Sufficiency and Elite Misrepresentation of Rural Livelihoods." In Saying the Unsayable: Monarchy and Democracy in Thailand, edited by Søren Ivarsson and Lotte Isager, 241-66. Copenhagen: Nordic Institute of Asian Studies Press.

World Health Organization (WHO)

2010 "Adelaide Statement on Health in All Policies: Moving towards A Shared Governance for Health and Well-Being." Report from the International Meeting on Health in All Policies, Adelaide 2010. http://www.who.int/social_ determinants/publications/countryaction/adelaide_statement_hiap/en/.

World Health Organization (WHO), and the Ministry of Social Affairs and Health, Finland

2013 "The Helsinki Statement on Health in All Policies." Adopted at the 8th Global Conference on Health Promotion, June 10-14. http://www.who.int/ healthpromotion/conferences/8gchp/statement_2013/en/. 